\title{
Tropical Atlantic Contributions to Strong Rainfall Variability Along the Northeast Brazilian Coast
}

\author{
G. A. Hounsou-gbo, ${ }^{1}$ M. Araujo, ${ }^{1}$ B. Bourlès, ${ }^{2,3}$ D. Veleda, ${ }^{1}$ and J. Servain ${ }^{1,4}$ \\ ${ }^{1}$ Laboratório de Oceanografia Física Estuarina e Costeira (LOFEC), Departamento de Oceanografia da Universidade Federal de \\ Pernambuco (UFPE), Cidade Universitária, Avenue Arquitetura s/n, 50740-550 Recife, PE, Brazil \\ ${ }^{2}$ Institut de Recherche Pour le Développement (IRD), LEGOS, Centre IRD de Bretagne, Technopole Pointe du Diable, BP 70, \\ 29280 Plouzané, France \\ ${ }^{3}$ International Chair in Mathematical Physics and Applications (ICMPA), UNESCO Chair, UAC, 072 P.O. Box 50, Cotonou, Benin \\ ${ }^{4}$ LOCEAN, IRD/CNRS/UPMC/MNHN, UMR 7159, Université Pierre et Marie Curie aile 45-55, 4e étage, 4 Place Jussieu, \\ 75252 Paris Cedex 05, France
}

Correspondence should be addressed to G. A. Hounsou-gbo; h.aubains@gmail.com

Received 22 July 2014; Accepted 9 September 2014

Academic Editor: Luis Gimeno

Copyright (C) 2015 G. A. Hounsou-gbo et al. This is an open access article distributed under the Creative Commons Attribution License, which permits unrestricted use, distribution, and reproduction in any medium, provided the original work is properly cited.

\begin{abstract}
Tropical Atlantic (TA) Ocean-atmosphere interactions and their contributions to strong variability of rainfall along the Northeast Brazilian (NEB) coast were investigated for the years 1974-2008. The core rainy seasons of March-April and June-July were identified for Fortaleza (northern NEB; NNEB) and Recife (eastern NEB; ENEB), respectively. Lagged linear regressions between sea surface temperature (SST) and pseudo wind stress (PWS) anomalies over the entire TA and strong rainfall anomalies at Fortaleza and Recife show that the rainfall variability of these regions is differentially influenced by the dynamics of the TA. When the Intertropical Convergence Zone is abnormally displaced southward a few months prior to the NNEB rainy season, the associated meridional mode increases humidity and precipitation during the rainy season. Additionally, this study shows predictive effect of SST, meridional PWS, and barrier layer thickness, in the Northwestern equatorial Atlantic, on the NNEB rainfall. The dynamical influence of the TA on the June-July ENEB rainfall variability shows a northwestward-propagating area of strong, positively correlated SST from the southeastern TA to the southwestern Atlantic warm pool (SAWP) offshore of Brazil. Our results also show predictive effect of SST, zonal PWS, and mixed layer depth, in the SAWP, on the ENEB rainfall.
\end{abstract}

\section{Introduction}

The nearly 60 million inhabitants of Northeast Brazil (NEB) are often affected by long periods of drought or by strong rainy episodes that can induce catastrophic floods. The drought periods are especially dramatic in the large, semiarid region of the NEB countryside $[1,2]$, where the rural population is primarily dependent on subsistence agriculture [3]. The strong rainy episodes, which generally occur in the NEB coastal region, also have dramatic consequences for the regional economy. These episodes can cause numerous fatalities. For instance, in June 2010, more than 1000 people disappeared due to hazardous floods in a few small cities of eastern coastal NEB [4].
The dynamics of the seasonal rainfall in semiarid NEB and the various causes of its interannual variability have been previously documented [5-8]. Indeed, the NEB rainfall regime is forced by the sum of various climatic components. Three of these components concern the tropical Atlantic basin. The seasonal latitudinal migration of the intertropical convergence zone (ITCZ) over the tropical Atlantic is the first mechanism that induces precipitation in the region [5]. In response to the warming of sea surface temperature (SST), the humid ITCZ reaches its southernmost latitude near the equator during the austral summer (February-March) [9]. This physical pattern is particularly important for the seasonal rainfall in northern NEB (hereafter called NNEB; see dotted red box in Figure 1(a)) that occurs primarily between 


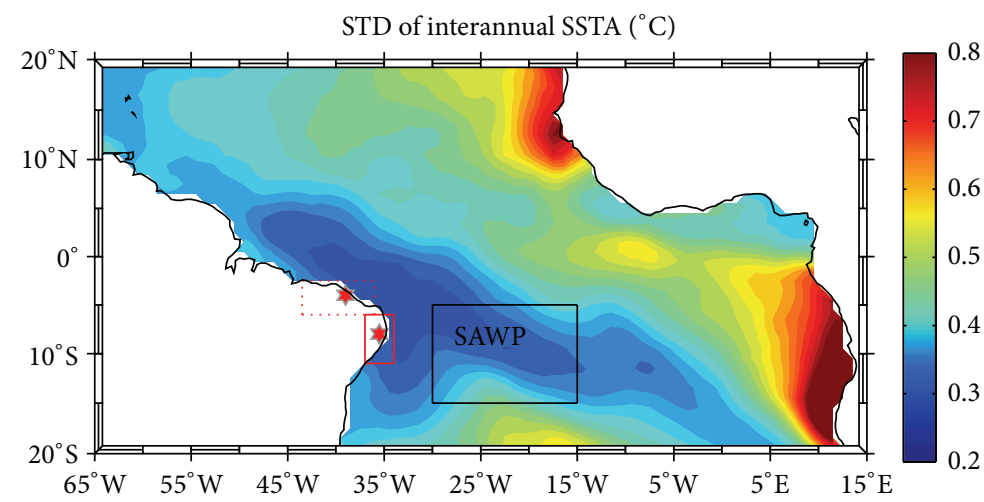

(a)

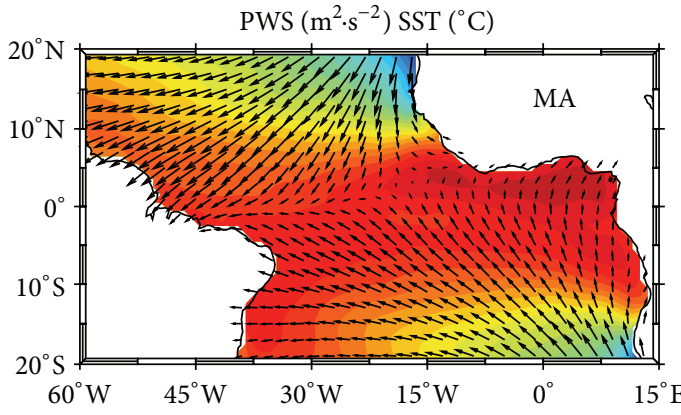

$-100 \mathrm{~m}^{2} \cdot \mathrm{s}^{-2}$

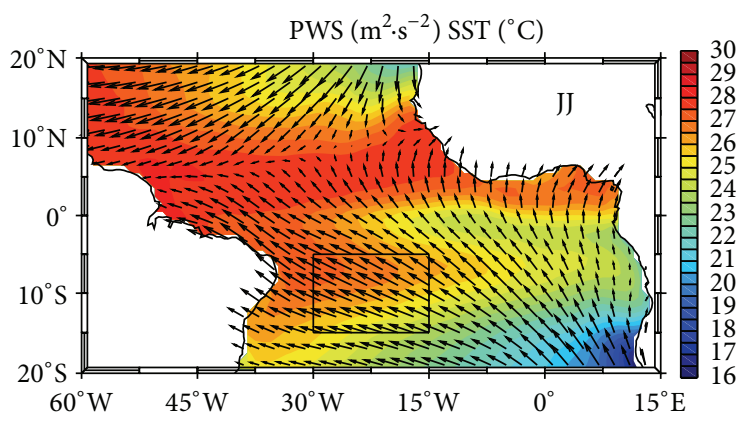

$-100 \mathrm{~m}^{2} \cdot \mathrm{s}^{-2}$

(b)

FIGURE 1: (a) Standard deviation of tropical Atlantic monthly SST anomalies. Anomalies are relative to the 1974-2008 seasonal average. The dotted red box indicates northern Northeast Brazil (NNEB, $43^{\circ}-38^{\circ} \mathrm{W}$ and $5^{\circ}-3^{\circ} \mathrm{S}$ ) which corresponds to the area average of GPCC precipitation; Fortaleza is represented by the red star. The full red box indicates eastern Northeast Brazil $\left(\mathrm{ENEB}, 36^{\circ}-34^{\circ} \mathrm{W}\right.$ and $\left.10^{\circ}-6^{\circ} \mathrm{S}\right)$ which corresponds to the area average of GPCC precipitation; Recife is represented by the red star. (b) 1974-2008 averages (March-April top, June-July bottom) of SST ( ${ }^{\circ} \mathrm{C}$; shaded) from OAFlux and Servain pseudo wind stress $\left(\mathrm{m}^{2} / \mathrm{s}^{2}\right.$, vectors). The black box in (a) and in the bottom panel of (b) indicates the offshore Brazil southwestern Atlantic warm pool (SAWP), which is a region of weak seasonal to interannual variability of SST that can be used for ENEB rainfall forecasting, as shown below.

February and May (see refs. above). When the ITCZ is abnormally positioned northward by a few degrees during these months, an SST anomaly gradient (positive phase of the Atlantic meridional mode, AMM) is generally observed with warmer SST to the north and colder SST to the south. During the positive (negative) phase of the AMM, the NE (SE) trade system is weaker (stronger) than normal, and the precipitation over NNEB is generally weaker (more intense) than normal $[10,11]$.

The NEB rainy season is also modulated by northward incursions of cold fronts from the South Atlantic Ocean. These cold fronts, linked to the episodic South Atlantic convergence zone (SACZ), cross NEB in the northwestward direction from the southern Brazilian coastline [12]. These events generate atmospheric instability and contribute to increased precipitation over all of $\mathrm{NEB}$, especially in the midsouthern region between November and March.

Crossing the south-equatorial Atlantic basin from West Africa to South America [13, 14], atmospheric easterly waves (EWs) are the third regional component of the seasonal rainfall regime over NEB. This process is especially important in eastern NEB (hereafter called ENEB; see full red box in Figure 1(a)). EWs are associated with clusters of well-defined mesoscale convective systems (MCSs) $[15,16]$ that generate large amounts of rainfall over ENEB. Kouadio et al. [4] indicated that such strengthening of the mesoscale convective activity in the oceanic region close to ENEB is concomitant with southeasterly wind intensification during the late boreal spring. These winds blow in a direction perpendicular to the ENEB coast [6]. The acceleration of the easterly trade winds over the south-equatorial Atlantic is associated with a slow warming at the surface and subsurface in the southwestern equatorial basin. Excess atmospheric moisture transported westward from Africa to South America generates substantial precipitation in ENEB [4].

Remote processes, such as those originating from the equatorial Pacific linked to El Niño or La Niña episodes and those from the midlatitudes in the Atlantic Ocean linked to the North Atlantic Oscillation (NAO), are the final external cause of the rainfall variability in NEB. El Niño (or La Niña) episodes, which generally peak at the end of December (hence the name "El Niño"), are often associated with weak (excess) 
precipitation a few weeks later in NNEB $[8,17]$. The regional climatic consequences are accentuated when the positive (negative) configuration of the AMM is concomitant with an El Niño (La Niña) episode [18]. The positive (negative) phase of the NAO, which corresponds to a strengthening of the atmospheric circulation in the North Atlantic midlatitudes, is generally associated with a negative (positive) evolution of the AMM $[19,20]$.

In this paper, we focus on the seasonal to interannual variability of tropical Atlantic Ocean-atmosphere state variables, such as SST and pseudo wind stress (PWS), and their lagged correlations with strong rainfall events in the NNEB and ENEB regions. In particular, we analyze differences and similarities between strong variability of the NNEB and ENEB rainy seasons and tropical Atlantic Ocean-atmosphere previous forcing. Furthermore, we also analyzed the ocean subsurface features such as mixed layer depth (MLD) and barrier layer thickness (BLT) in order to understand their potential relationships with interannual variability of Oceanatmosphere variables. The main goal is to identify early state variable patterns that can be used for predicting strong rainfall variability over these regions.

The data and methods are presented in the following section. Section 3 presents the elements of climatic variability over the tropical Atlantic, with emphasis on the identification of the early oceanic contributions to Fortaleza (NNEB) and Recife (ENEB) rainfall variability. A summary of the study is then provided.

\section{Data and Methods}

2.1. Surface Meteorological Data: Rainfall, SST, and PWS. The precipitation dataset used in this paper is composed of monthly rainfall observations at Fortaleza, CE $\left(3^{\circ} 43^{\prime} \mathrm{S}\right.$ and $\left.38^{\circ} 32^{\prime} \mathrm{W}\right)$, which are representative of NNEB, and at Recife, $\mathrm{PE}\left(8^{\circ} \mathrm{S}\right.$ and $\left.34^{\circ} 52^{\prime} \mathrm{W}\right)$, which are representative of ENEB (Figure 1(a)), during 1974-2008; these data were obtained from the Fundação Cearense de Meteorologia e Recursos Hídricos (http://www.funceme.br) and from the Instituto Nacional de Meteorologia (http://www.inmet.gov.br), respectively. Our analysis is limited to 1974-2008 due to the homogeneity of Fortaleza FUNCEME data during this period. In the previous lines of this paragraph, we mentioned that stations data at Fortaleza and Recife are representative of $\mathrm{NNEB}\left(43^{\circ}-38^{\circ} \mathrm{W}\right.$ and $\left.5^{\circ}-3^{\circ} \mathrm{S}\right)$ and $\operatorname{ENEB}\left(36^{\circ}-34^{\circ} \mathrm{W}\right.$ and $\left.10^{\circ}-6^{\circ} \mathrm{S}\right)$, respectively. This consideration is based on the fact that the correlation coefficients between NNEB and ENEB area-averages precipitation from the Global Precipitation Climatology Centre (http://www.esrl.noaa.gov/ $\mathrm{psd} /$ data/gridded/data.gpcc.html) and stations rainfall at Fortaleza and Recife are 0.88 and 0.92 , respectively (figure not shown). We chose to use directly these stations rainfall, rather than the GPCC data, since they present a higher quality and especially they are available in real time (reanalysis from GPCC being available after many months delay). In the following, mentioning Fortaleza and Recife should refer to NNEB and ENEB, respectively.

Monthly pseudo wind stress (PWS) vectors with a $2^{\circ} \times 2^{\circ}$ resolution were obtained from the Servain dataset [21-24] and downloaded from FUNCEME (http://www.funceme.br); the data are available for the period 1964 to present. Individual pseudo wind stress components (PWSx and PWSy in $\mathrm{m}^{2} / \mathrm{s}^{2}$ ) are defined as the wind velocity (in $\mathrm{m} / \mathrm{s}$ ) multiplied by the wind's zonal and meridional components (in $\mathrm{m} / \mathrm{s}$ ). Monthly averaged SST data were obtained from the Objectively Analyzed air-sea Fluxes Project (OAFlux) $\left(1^{\circ} \times 1^{\circ}\right.$ resolution $)$ and are available for the period $1958-$ 2012 from Woods Hole Oceanographic Institution (WHOI) (http://oaflux.whoi.edu). OAFlux provides a synthesized product using NCEP1, NCEP2, ERA40, and ERA-interim reanalysis [25-27].

The variables used in Figure 1(b) are SST (from OAFlux) and PWS (from Servain dataset). During the March-April period, considered in the following as the core rainy season at Fortaleza (NNEB), SST is higher $\left(>28^{\circ} \mathrm{C}\right)$ in the northwestern equatorial Atlantic (NEA) and the SAWP $\left(30^{\circ}-15^{\circ} \mathrm{W}\right.$ and $15^{\circ}-$ $5^{\circ} \mathrm{S}$ ) regions (Figure $1(\mathrm{~b})$, top-left panel). The higher SST is associated with the southern position (near the equator) of the ITCZ [28], which coincides with the northeasterly wind intensification.

During June-July, which corresponds in the following to the core rainy season at Recife (ENEB), higher equatorial SST $\left(>27^{\circ} \mathrm{C}\right)$ presents a northward displacement as a result of the northward shifting of the ITCZ (Figure 1(b), bottom panel). However, the SAWP (black box in (a) and in the bottom panel of (b)) shows weak variation of SST $\left(>27^{\circ} \mathrm{C}\right)$ with a seasonal variability less than $2^{\circ} \mathrm{C}$ [29-33]. This region also presents weak interannual SST variability, where the standard deviation of monthly anomalies is $0.2-0.3^{\circ} \mathrm{C}$ (Figure $1(\mathrm{a})$ ).

The interannual variability of these quantities was estimated by removing the 1974-2008 climatological annual cycle from all monthly averages of SST, PWS, and rainfall fields. The linear trend was also removed from all resulting anomalies. Concomitant and lagged linear regressions between the climatic variables over the tropical Atlantic and the rainfall quantities measured at Fortaleza and Recife were computed to estimate the mutual relationships between the variables.

\subsection{Subsurface Ocean Data: Isothermal Layer Depth (ILD)} and Mixed Layer Depth (MLD) Criteria. Since the seasonal evolution of the Ocean-atmosphere variables is generally related to the Ocean subsurface features such as depth of warm water, we estimated the isothermal layer depth (ILD) and the barrier layer thickness (BLT) in order to analyze their potential influence on the strong rainfall variability. We chose to estimate both the ILD and the BLT because previous studies have shown their importance on the seasonal evolution of the Ocean-atmosphere variables in the western equatorial Atlantic (offshore of NEB) [34-36].

We used temperature and salinity reanalysis from SODA (http://iridl.ldeo.columbia.edu/SOURCES/.CARTON-GIESE /.SODA/) to determine the ILD and mixed layer depth (MLD), which are used to estimate the BLT.

(i) The ILD is determined using the temperature criterion with $\Delta T=-0.5^{\circ} \mathrm{C}$ [36]. Using this criterion, the ILD corresponds to the depth at which temperature is 


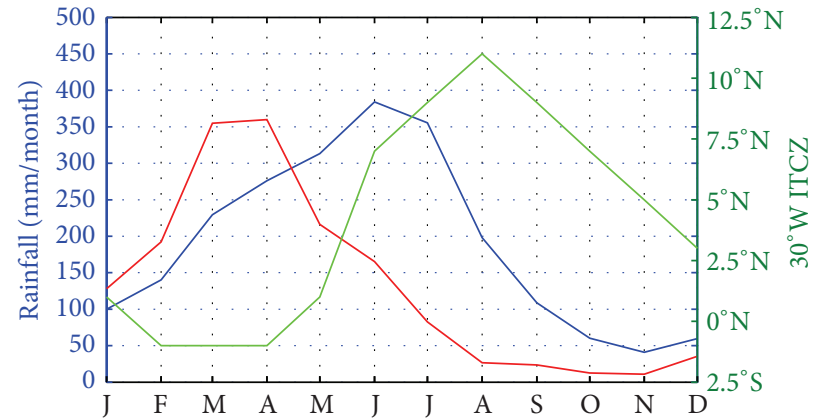

Figure 2: Recife (blue) and Fortaleza (red) monthly rainfall climatologies (mm/month, 1974-2008). The green line represents the position of the ITCZ's proxy (see the text for the definition of this proxy).

equal to SST $+\Delta T$, where SST is temperature value at the reference depth Zref $=5 \mathrm{~m}$.

(ii) The MLD is determined using the density $(\sigma)$ criterion with $\Delta \sigma=\sigma\left(\mathrm{SST}+\Delta T, \mathrm{SSS}, P_{0}\right)-\sigma\left(\mathrm{SST}, \mathrm{SSS}, P_{0}\right)$ [36-38]. SST and SSS are temperature and salinity values at the reference depth $(\mathrm{Zref}=5 \mathrm{~m})$ and $P_{0}$ is the pressure at the ocean surface. With this criterion MLD corresponds to the depth at which density is equal to $\sigma_{0}+\Delta \sigma$, where $\sigma_{0}$ is density value at the reference depth Zref $=5 \mathrm{~m}$.

(iii) The BLT is the difference between ILD and MLD [36].

\section{Results}

3.1. Seasonal Variability of Rainfall at Fortaleza (NNEB) and Recife (ENEB). Figure 2 shows the climatological annual cycles of the monthly rainfall at Fortaleza and Recife for 19742008 as well as the climatology of the seasonal latitudinal migration of a proxy of the ITCZ. According to Servain et al. [21], the ITCZ proxy is defined as the latitude where the meridional component of the wind at the center of the Atlantic basin (here, along $30^{\circ} \mathrm{W}$ ) is equal to zero. By this definition, the ITCZ seasonally ranges over $11^{\circ}$ of latitude. It remains just south of the equator for approximately three months (February-March-April) and reaches its northern position $\left(\sim 11^{\circ} \mathrm{N}\right)$ in August (Figure 2).

The core of the rainfall season at Fortaleza increases rapidly during the stationary southern position of the ITCZ from February $(\sim 180 \mathrm{~mm} / \mathrm{month})$ to a maximum $(350 \mathrm{~mm} /$ month) in March-April. It remains consistent $(200 \mathrm{~mm} /$ month) in May when the ITCZ moves poleward. The prerainy season in January-February and postrainy season in June (approximately $170 \mathrm{~mm} /$ month for both) complete the seasonal rainfall cycle at Fortaleza (NNEB). The rest of the year is dry $(<100 \mathrm{~mm} / \mathrm{month})$ or very dry $(<10 \mathrm{~mm} / \mathrm{month}$ in October-November).

The seasonal precipitation at Recife (ENEB) is completely different. Here, the core of the rainfall season $(>350 \mathrm{~mm} /$ month) occurs in June-July, that is, during the poleward progression of the ITCZ. The prerainy season at Recife

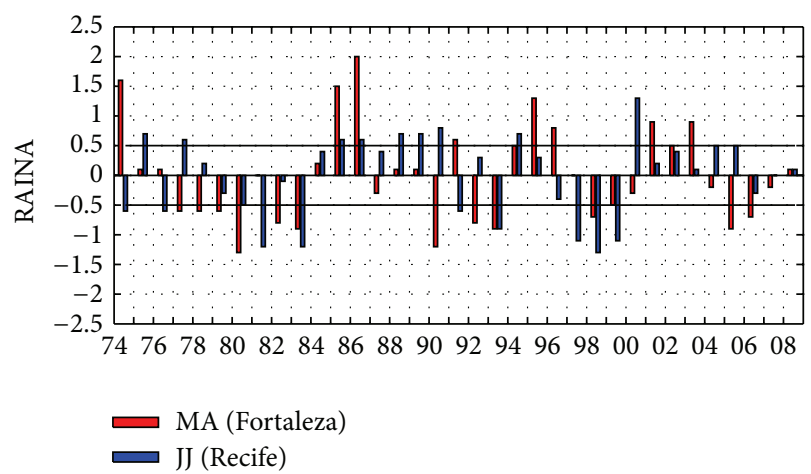

FIGURE 3: Diagram of rainfall anomalies (RAINA) at Fortaleza (March-April, red bars) and Recife (June-July, blue bars). All anomalies are detrended and normalized by their standard deviations $(156 \mathrm{~mm} / \mathrm{month}$ for both Fortaleza and Recife). The threshold of \pm 0.5 is indicated by the bold horizontal lines.

(from 140 to $300 \mathrm{~mm} / \mathrm{month}$ ) occurs over four months (February-March-April-May), while the postrainy season occurs in August $(\sim 200 \mathrm{~mm} / \mathrm{month})$. The dry season ( $<100 \mathrm{~mm} /$ month) occurs from September to January, with the minimum ( $<50 \mathrm{~mm} / \mathrm{month}$ ) occurring in November.

A longer extent of the full rainfall season at Recife (7 months, compared with 5 months at Fortaleza), combined with the core of the rainfall season in June-July, which is disconnected from the southernmost position of the ITCZ indicates that the rainfall season in the ENEB region is a complex response to the regional climatic environment. This topic will be discussed in more detail in the following section.

3.2. Oceanic Contributions to Strong Rainfall Variability at Fortaleza (NNEB) and Recife (ENEB). Because our main objective is to study extreme episodes (wettest or driest) of the rainfall seasons, we only selected the observed rainy events that exceeded an instantaneous threshold of \pm 0.5 (standardized rainfall anomalies higher than +0.5 and lower than -0.5 , Figure 3 ) during the available 35 years (19742008) for the core of the seasonal rainfall at Fortaleza-NNEB (i.e., March-April) and for the core of the seasonal rainfall at Recife-ENEB (i.e., June-July). For Fortaleza, we selected 20 years (57\% of the 35 years) of strong rainfall variability; 8 of the years have strong positive 2 -month average (MA) anomalies, and 12 of the years have strong negative 2-month average (MA) anomalies (Figure 3 and Table 1). At Recife, 18 years (51\% of the 35 years) were selected; 9 of the years have strong positive 2-month average (JJ) anomalies, and 9 of the years have strong negative 2 -month average (JJ) anomalies (Figure 3 and Table 1).

Over the 35-year period, positive anomalies of rainfall at Fortaleza present a low frequency signal, with positive events that last 2 to 3 years. During the following 3-year periods, that is, 1974-1976, 1984-1986, 1994-1996, and 2001-2003, positive rainfall anomalies were observed in this region in MarchApril. These 3-year periods of positive rainfall anomalies were generally composed of 2 strong events $(>+0.5)$, except for the period of 1974-1976, which only experienced 1 strong event 
TABLE 1: Years corresponding to the selected positive (bold) and negative (bold italic) rainfall anomalies with a threshold of \pm 0.5 at Fortaleza in March-April (MA) and at Recife in June-July (JJ).

\begin{tabular}{|c|c|c|c|}
\hline \multicolumn{2}{|c|}{ FORTALEZA } & \multicolumn{2}{|c|}{ RECIFE } \\
\hline Years & RAINA (MA) & Years & RAINA (JJ) \\
\hline 1974 & +1.6 & 1974 & -0.6 \\
\hline 1975 & +0.1 & 1975 & +0.7 \\
\hline 1976 & +0.1 & 1976 & -0.6 \\
\hline 1977 & -0.6 & 1977 & +0.6 \\
\hline 1978 & -0.6 & 1978 & +0.2 \\
\hline 1979 & -0.6 & 1979 & -0.3 \\
\hline 1980 & -1.3 & 1980 & -0.5 \\
\hline 1981 & 0 & 1981 & -1.2 \\
\hline 1982 & -0.8 & 1982 & -0.1 \\
\hline 1983 & -0.9 & 1983 & -1.2 \\
\hline 1984 & +0.2 & 1984 & +0.4 \\
\hline 1985 & +1.5 & 1985 & +0.6 \\
\hline 1986 & +2 & 1986 & +0.6 \\
\hline 1987 & -0.3 & 1987 & +0.4 \\
\hline 1988 & +0.1 & 1988 & +0.7 \\
\hline 1989 & +0.1 & 1989 & +0.7 \\
\hline 1990 & -1.2 & 1990 & +0.8 \\
\hline 1991 & +0.6 & 1991 & -0.6 \\
\hline 1992 & -0.8 & 1992 & +0.3 \\
\hline 1993 & -0.9 & 1993 & -0.9 \\
\hline 1994 & +0.5 & 1994 & +0.7 \\
\hline 1995 & +1.3 & 1995 & +0.3 \\
\hline 1996 & +0.8 & 1996 & -0.4 \\
\hline 1997 & 0 & 1997 & -1.1 \\
\hline 1998 & -0.7 & 1998 & -1.3 \\
\hline 1999 & -0.5 & 1999 & -1.1 \\
\hline 2000 & -0.3 & 2000 & +1.3 \\
\hline 2001 & +0.9 & 2001 & +0.2 \\
\hline 2002 & +0.5 & 2002 & +0.4 \\
\hline 2003 & +0.9 & 2003 & +0.1 \\
\hline 2004 & -0.2 & 2004 & +0.5 \\
\hline 2005 & -0.9 & 2005 & +0.5 \\
\hline 2006 & -0.7 & 2006 & -0.3 \\
\hline 2007 & -0.2 & 2007 & 0 \\
\hline 2008 & +0.1 & 2008 & +0.1 \\
\hline
\end{tabular}

(RAINA > +1.5 in 1974). Two other major events of rainfall with anomalies exceeding +1.5 were observed in 1985 and 1986. For negative anomalies of rainfall at Fortaleza, we also observed a low frequency signal; these negative events have 3to 7-year durations over our study period. From 1977 to 1983 , Fortaleza experienced a dry episode during which 6 of the 7 years showed strong negative rainfall anomalies $(<-0.5)$. Other dry episodes were observed during 1992-1993, 19982000, and 2005-2007.

At Recife, the rainfall shows long periods of positive and negative anomalies (Figure 3, Table 1). From 1984 to 1990 , 7 positive events were observed over this region, with 5 anomalies exceeding $+0.5(1985,1986,1988,1989$, and 1990).
Another period of positive events ranges from 2000 to 2005, with only 1 anomaly exceeding +0.5 (2000). The positive anomaly observed during the year 2000 appears to be the highest in this region for the study period. Long periods of negative anomalies were observed from 1979 to 1983 (5 years) and from 1996 to 1999 (4 years). The driest period at Recife was observed from 1997 to 1999, when 3 events involved strong negative anomalies $(<-1)$.

Comparing the selected years of strong events at Fortaleza (20 events) and at Recife (18 events) from 1974 to 2008, we observe that only 9 selected years are common to both locations, producing a set of $29(20+18-9)$ years (Table 1$)$. During these 9 common years, only 5 events have the same sign, 2 years (1985 and 1986) have strong positive rainfall anomalies, and 3 years $(1983,1993$, and 1998) have strong negative rainfall anomalies (Table 1). For the other 4 common years (1974, 1977, 1990, and 1991) of strong events, Fortaleza and Recife experienced opposite events (i.e., dry episode at Fortaleza and wet episode at Recife). We can conclude that the responses of strong events at Fortaleza and Recife to the tropical Atlantic Ocean-atmosphere interactions are different for 5/6 (24/29) cases. These observations support the hypothesis that differences in dynamics influence the difference in responses documented at Fortaleza and Recife.

To analyze the potential influence of the oceanatmosphere variables on the strong rainfall variability of NEB coastal areas, we performed a linear regression between the interannual monthly anomalies of SST (SSTA), PWS (PWSA), and rainfall (RAINA) for the 20 and 18 selected years of strong rainfall variability at Fortaleza and Recife, respectively (Figures 4 and 5, resp.).

The SST and PWS 2-month anomalies were calculated for each core of the rainy season of Fortaleza (i.e., MA) and Recife (i.e., JJ) and for the previous 4 series of 2-month periods (i.e., FM, JF, DJ, and ND for Fortaleza and MJ, AM, MA, and FM for Recife). Figures 4 and 5 show the coefficients of the linear regressions (in $\mathrm{mm} / \mathrm{month} /{ }^{\circ} \mathrm{C}$ ) between the surface ocean-atmosphere variables and rainfall anomalies for the strong events in Table 1 for Fortaleza and Recife, respectively. These regressions are related to each of the 52 -month periods indicated above for both Fortaleza and Recife.

The linear regression at zero lag (i.e., during March-April; MA) between 20 years of strong RAINA at Fortaleza and the tropical Atlantic variables (Figure 4, bottom right-hand panel) exhibits an obvious meridional mode pattern for SST and PWS. A strong negative relationship is observed with SST in the northwestern region of the tropical Atlantic (highest values $<-280 \mathrm{~mm} / \mathrm{month} /{ }^{\circ} \mathrm{C}$ off the mouth of the Amazon), and a positive relationship (up to $+280 \mathrm{~mm} / \mathrm{month} /{ }^{\circ} \mathrm{C}$ ) is observed in a zonal region immediately south of the equator from $25^{\circ} \mathrm{W}$ to the Gulf of Guinea (near $0^{\circ} \mathrm{W}$ ). Such an SST pattern agrees with the positive impact of the AMM (cold in the North, warm in the South), which is widely discussed in the literature, on the NNEB rainfall variability $[1,39]$. However, the present analysis yields an additional understanding of the remote dynamic processes. Indeed, in the months antecedent to the seasonal rainfall at Fortaleza, from November-December (4-month lag) to March-April (zero lag), the positive southern pattern of the AMM gradually 

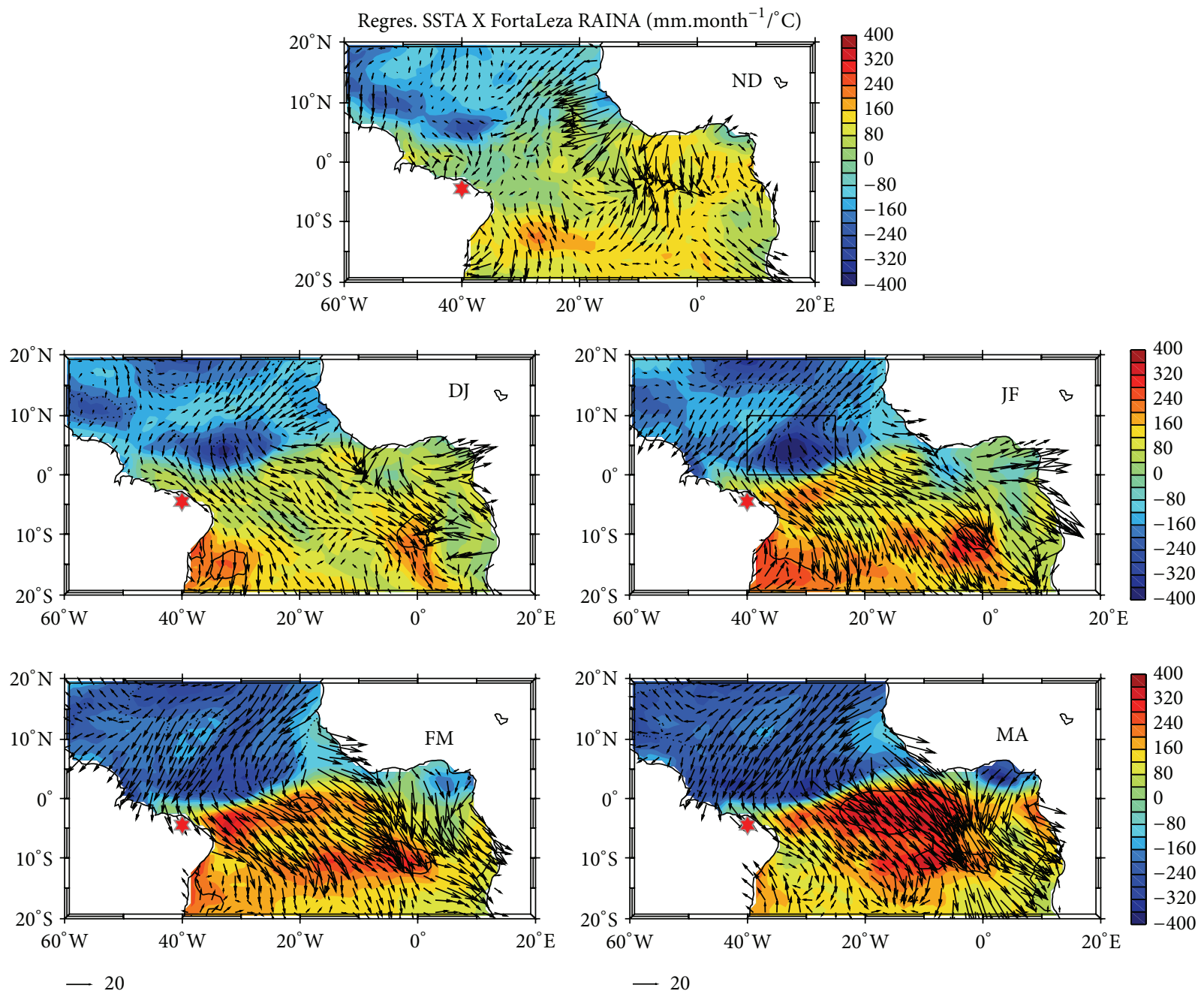

FIGURE 4: Distributions of lagged linear regression coefficients (1974-2008) between the interannual rainfall anomalies for very wet (>+0.5) and very dry $(<-0.5)$ years in Fortaleza-NNEB (red star) during March-April and the interannual SST anomalies during the years selected above in the tropical Atlantic for March-April (zero lag), February-March, January-February, December-January, and November-December $\left(4\right.$-month lag) $\left(\mathrm{mm} \cdot \mathrm{month}^{-1} /{ }^{\circ} \mathrm{C}\right)$. The vectors $\left(\mathrm{mm} \cdot \mathrm{month}^{-1} / \mathrm{m}^{2} \cdot \mathrm{s}^{-2}\right)$ represent linear regressions between the interannual rainfall anomalies and the interannual PWS (PWSx and PWSy) anomalies. The 95\% significance level of correlation, according to a student $t$-test (and higher than 0.5 ), is plotted with a dotted line (negative) and a solid line (positive) for SSTA. Before averaging and plotting by 2-month periods, the linear trends are removed from all anomalies. The black box (NEA) relative to January-February (JF) represents a strongly influential SST variability area. NEA, which presents significant negative anomalies of SST from December-January to March-April, is used in the following for testing the forecasts of the rainfall season over NNEB.

develops, while the negative northern pattern continues to remain well organized mainly in the northwestern equatorial Atlantic (NEA), offshore of NNEB (Figure 4). Meanwhile, from the 4-month lag (November-December) to zero lag (March-April), a strong meridional perturbation of wind develops (Figure 4). A gradual, intense western equatorward relaxation of the SE trades and a gradual strengthening of the NE trades is observed from the 4-month lag to zero lag. Furthermore, in association with the subsequent formation of this AMM, the 3-4-month prior establishment of a meridional "wind dipole" (intensification in the north, relaxation in the south) also correlates with an excess of precipitation in NNEB in March-April.
A similar regression analysis between ocean-atmosphere (SSTA and PWSA) and precipitation anomalies was performed for Recife from the 4-month lag (i.e., FebruaryMarch) to zero lag (i.e., June-July) for the 18 years of strong rainfall variability (Figure 5). Although the SST meridional mode is weaker in intensity, it also appears here; it has a negative correlation in the northern tropical Atlantic and a positive correlation in the southern tropical Atlantic (Figure 1). In this case, however, we found a core of significant positive coefficients (up to $+210 \mathrm{~mm} / \mathrm{month} /{ }^{\circ} \mathrm{C}$ ) in the southern tropical Atlantic in the eastern part of the basin $\left(15^{\circ}-0^{\circ} \mathrm{W}\right.$ and $\left.10^{\circ}-20^{\circ} \mathrm{S}\right)$ in February-March (4-month lag). Based on the regression analysis, from the 4-month 

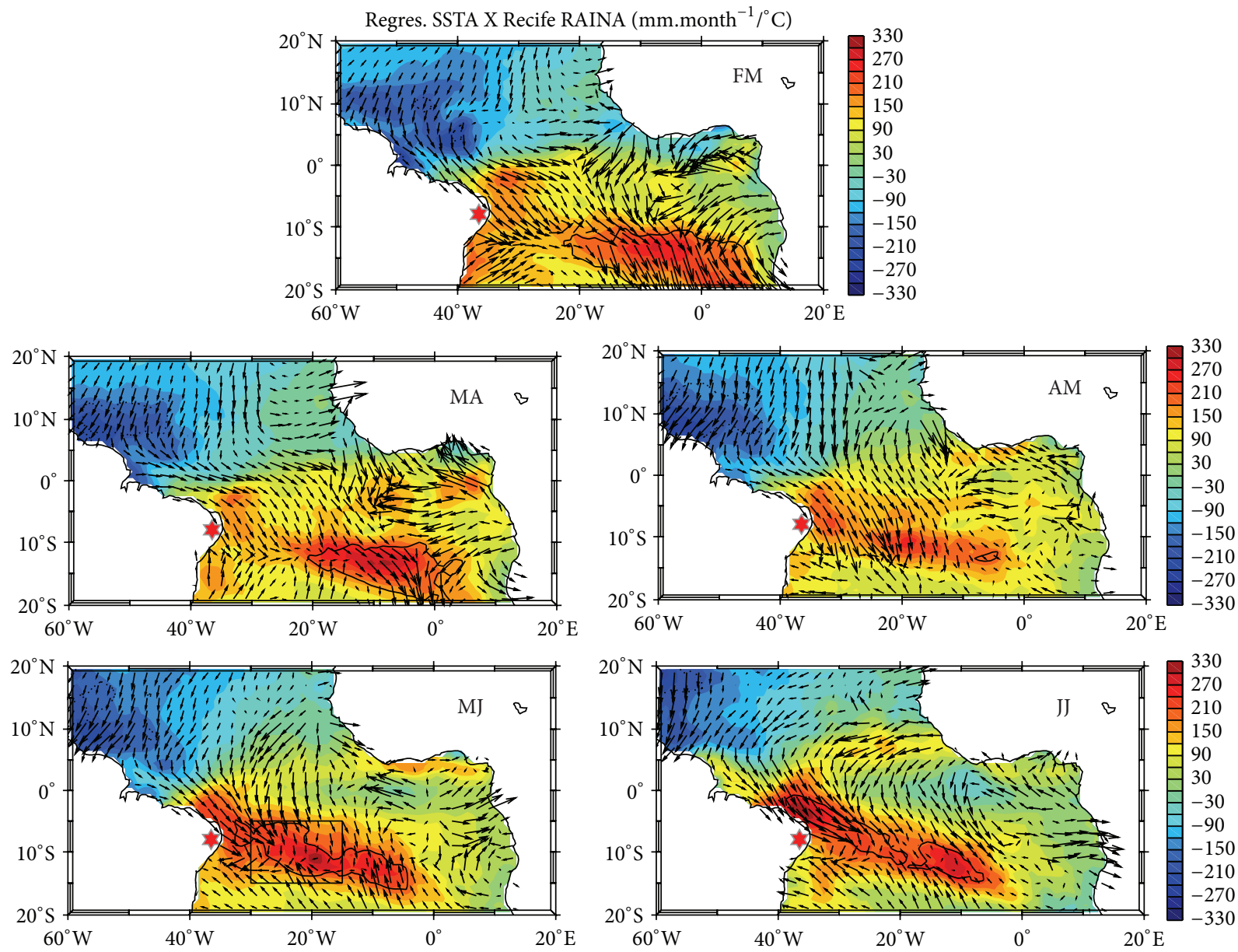

$-20$

$-20$

FiguRE 5: Distributions of lagged linear regression coefficients (1974-2008) between the interannual rainfall anomalies for very wet $(>+0.5)$ and very dry $(<-0.5)$ years in Recife-ENEB (red star) during June-July, and the interannual SST anomalies during the years selected above in the tropical Atlantic for June-July (zero lag), May-June, April-May, March-April, and February-March (4-month lag) (mm.month $\left.{ }^{-1} /{ }^{\circ} \mathrm{C}\right)$. The vectors $\left(\mathrm{mm} \cdot \mathrm{month}^{-1} / \mathrm{m}^{2} \cdot \mathrm{s}^{-2}\right)$ represent linear regressions between the interannual rainfall anomalies and the interannual PWS (PWSx and PWSy) anomalies. The 95\% significance level of correlation, according to a student $t$-test (and higher than 0.5), is plotted with a dotted line (negative) and a solid line (positive) for SSTA. Before averaging and plotting by 2-month periods, the linear trends are removed from all anomalies. The black box (SAWP) relative to May-June (MJ) represents a strongly influential SST variability area. The SAWP, which shows an inversion of the surface wind anomaly and a positive correlation of SSTA in May-June, is used in the following for testing the forecasts of the rainfall season over ENEB.

to zero-month lag, the core of strong positive correlation (95\% significant level) shows a northwestward propagation. This signal propagates from the eastern part of the southern tropical Atlantic in February-March to the ENEB coast $\left(5^{\circ}-\right.$ $15^{\circ} \mathrm{S}$ ) in June-July. From the 4-month lag to zero lag of the regression analysis between the PWSA and the seasonal RAINA at Recife (Figure 5), our results show an abnormal strengthening of the southeasterly wind over the warm water in the southwestern tropical basin a few weeks before the rainy season in ENEB. Such acceleration of the SE trade system increases just before the ENEB rainy season and increases humidity and precipitation throughout the eastern part of the South America. The northwestward propagation of the significant correlation of SST anomalies observed in Figure 5 follows the same pathway of the westward flow of the southern branch of the South Equatorial current (sSEC), which is located between $10^{\circ} \mathrm{S}$ and $25^{\circ} \mathrm{S}$ [40]. The estimated speed of the western limit of the area of significant correlation from $20^{\circ} \mathrm{W}$ (February-March) to $35^{\circ} \mathrm{W}$ (June-July) near the ENEB coast is $\sim 0.16 \mathrm{~m} / \mathrm{s}$ based on 4 months between February-March and June-July (Figure 5). This velocity is comparable with the mean current speed of the sSEC south of $10^{\circ} \mathrm{S}$ in the tropical Atlantic, which was estimated as $\sim 0.15 \mathrm{~m} / \mathrm{s}$ by Richardson and McKee [41] and $\sim 0.10 \mathrm{~m} / \mathrm{s}$ by Stramma [40]. Near the Brazilian coast, the sSEC bifurcates between $17^{\circ} \mathrm{S}$ and $13^{\circ} \mathrm{S}$ into the southward Brazil Current (BC) and the North Brazil Undercurrent-North Brazil Current (NBUCNBC), which carries southern tropical Atlantic warm water to the Northern Hemisphere $[42,43]$. The northward direction of the positive correlation between SSTA and ENEB RAINA 


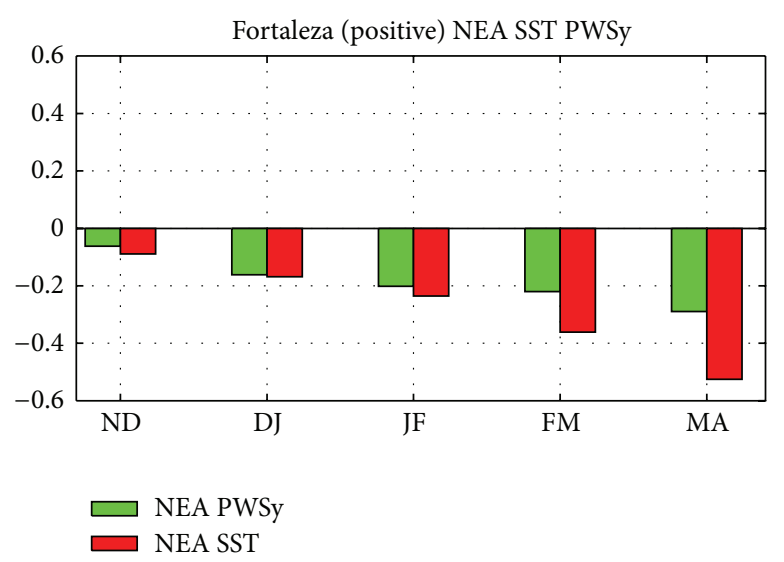

(a)

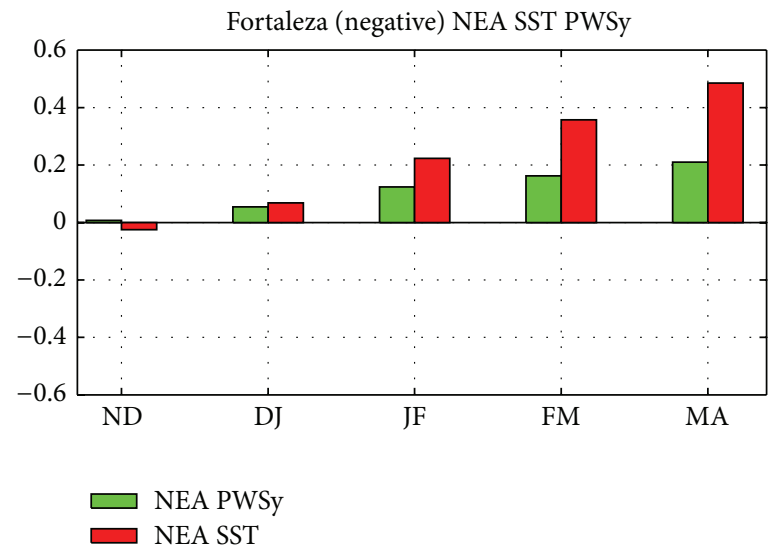

(c)

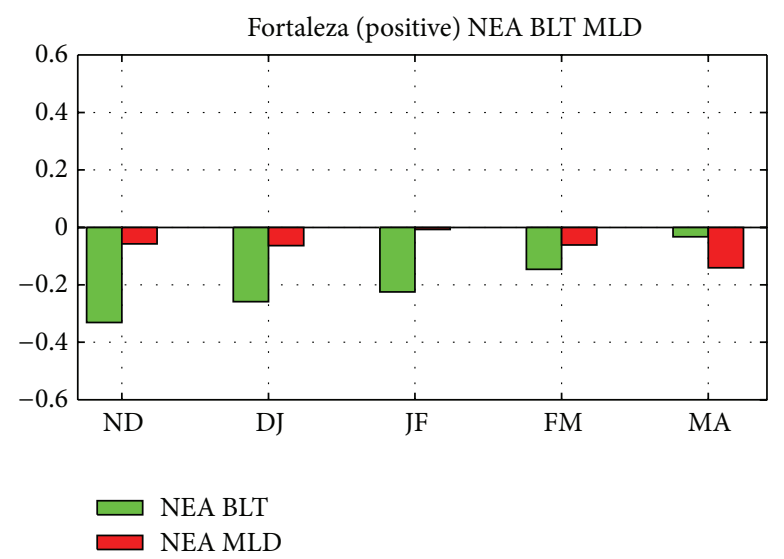

(b)

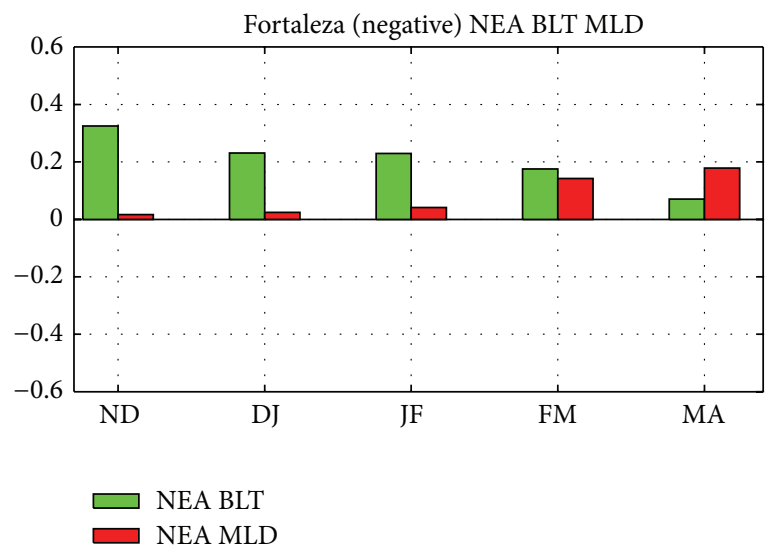

(d)

FIGURE 6: Temporal evolution of the NEA (averaged over $40^{\circ}-25^{\circ} \mathrm{W}$ and $0^{\circ}-10^{\circ} \mathrm{N}$ ) of SST and meridional PWS anomalies ((a) and (c)); MLD and BLT anomalies ((b) and (d)) from November-December (ND) to March-April (MA). ((a) and (b)) Composites are relative to 8 years of positive $(>+0.5)$ normalized rainfall anomalies at Fortaleza (NNEB), and (c) and (d) composites are relative to 12 years of negative $(<-0.5)$ normalized rainfall anomalies at Fortaleza (NNEB).

(Figure 5) along the NEB coast in June-July (0-month lag) supports the northward transport of heat to the Northern Hemisphere by the NBUC-NBC system and is documented in the literature $[40,43,44]$.

\subsection{Early Evolution of Oceanic Parameters Linked to Strong} Rainfall Variability. Figure 6(a) shows the evolution of the composite of SST and PWSy anomalies in the NEA $\left(40^{\circ}-\right.$ $25^{\circ} \mathrm{W}$ and $0^{\circ}-10^{\circ} \mathrm{N}$, black box in Figure 4, left panel: JanuaryFebruary) from November-December (ND) to March-April (MA) during the wettest years (Figure 6(a)) and the driest years (Figure 6(b)) at Fortaleza. We considered the meridional component of PWS (PWSy) in the NEA because it primarily influences the meridional mode (Figure 4 ). The NEA is considered for the forecasting index because this region presents strong negative correlations of SST and surface wind with NNEB rainfall from December-January to March-April. Our composite is based on the 8 years of heavy rainfall (RAINA $>+0.5$, Figure 3 , Table 1 ) and the 12 years of very dry episodes (RAINA $<-0.5$, Figure 3, Table 1 ) at Fortaleza. Here, positive (negative) anomalies of PWSy indicate a weakening (strengthening) of the meridional component of the northeasterly wind. For the composite of heavy rainfall years, both SST and PWSy in the NEA present negative anomalies that intensify from November-January to MarchApril (Figure 6(a)). The negative normalized SST anomaly in the NEA area intensifies from -0.09 in November-December to -0.52 in March-April. The negative normalized anomaly of PWSy in the NEA increases from -0.06 (NovemberDecember) to -0.28 (March-April). This evolution of SST and PWSy suggests that abnormal intensification of the meridional component of the northeasterly wind from NovemberDecember to March-April is associated with more evaporation and negative SST anomalies in the NEA, humidity transport to NNEB and heavy rainfall. The amplitudes of the variations of the normalized SST anomaly $(-0.43)$ and PWSy anomaly $(-0.22)$ from November-December to March-April suggest that the variation of the SST in the NEA has a greater effect on the NNEB heavy rainfall. 


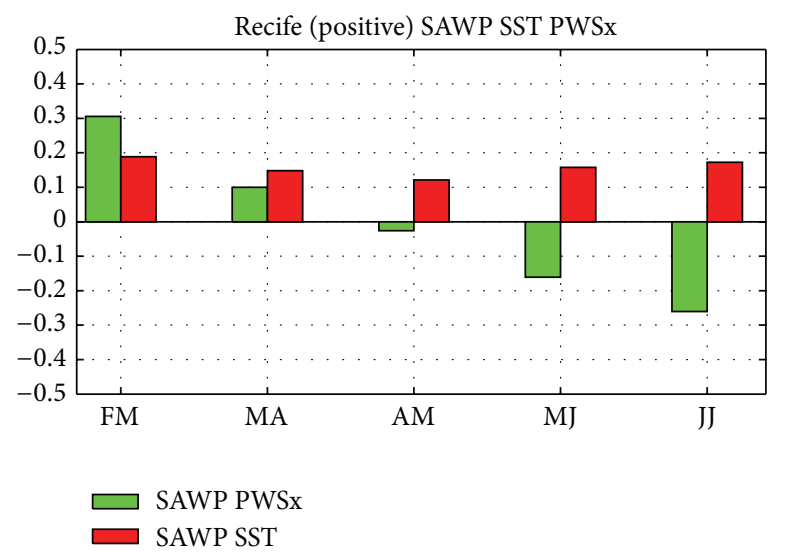

(a)

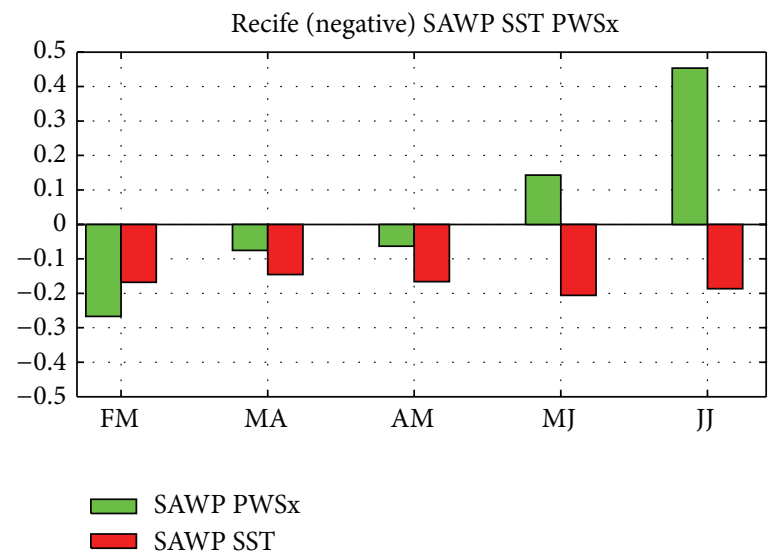

(c)

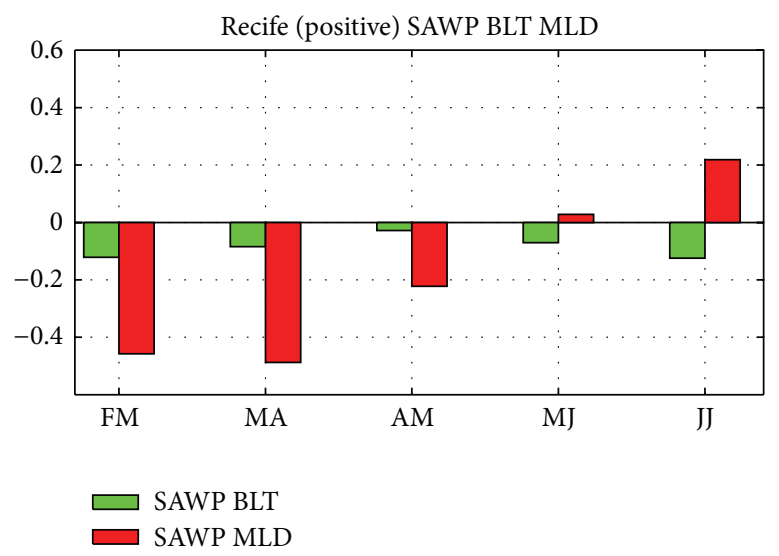

(b)

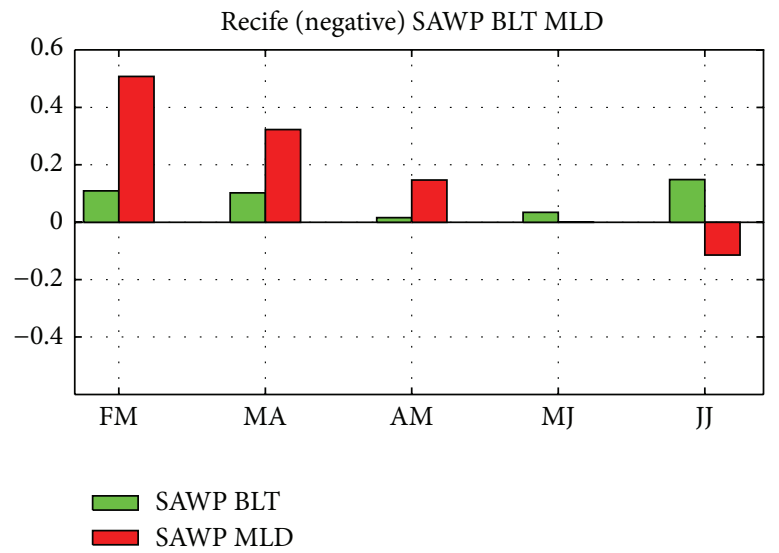

(d)

Figure 7: Temporal evolution of the SAWP (averaged over $30^{\circ}-15^{\circ} \mathrm{W}$ and $15^{\circ}-5^{\circ} \mathrm{S}$ ): SST and zonal PWS (averaged over $30^{\circ}-15^{\circ} \mathrm{W}$ and $20^{\circ}-$ $10^{\circ} \mathrm{S}$ for PWSx) anomalies ((a) and (c)); MLD and BLT anomalies ((b) and (d)) from February-March (FM) to June-July (JJ). ((a) and (b)) Composites are relative to 9 years of positive $(>+0.5)$ normalized rainfall anomalies at Recife (ENEB), and ((c) and (d)) Composites are relative to 9 years of negative $(<-0.5)$ normalized rainfall anomalies at Recife $(\mathrm{ENEB})$.

In order to look at possible lagged relationship between oceanic subsurface features in the NEA region and the Fortaleza heavy rainfall, Figure 6(b) shows evolution of the composite of mixed layer depth (MLD) and barrier layer thickness (BLT) anomalies from November-December (ND) to March-April (MA) during the wettest years. Since all climatological values of BLT (area averaged over both NEA and SAWP) are positive, negative (positive) anomaly of BLT indicates deep (shallow) salinity stratification within the isothermal layer. The strong negative anomaly of BLT increases from November-December (-0.32) to March-April $(-0.04)$. The comparison of the evolutions of the MLD and BLT during this period shows that the increase of BLT is not associated with increase of the MLD. This observation suggests that, during years of heavy rainfall in NNEB, the BLT in the NEA that is previously thinner than normal in November-December increases with the intensification of the meridional PWS, which is associated with negative anomaly of the SST.

Analyzing the composite of the driest years at Fortaleza, the normalized anomalies of SST and PWSy in the
NEA increase positively from December-January $(-0.02$ and +0.01 , resp.,) to March-April (+0.48 and +0.21 , resp.) (Figure 6(c)). Again, the amplitudes of the variations of the normalized SST anomaly $(+0.5)$ and PWSy anomaly $(+0.2)$ from November-December to March-April suggest that the variation of SST in the NEA has a greater effect on the NNEB dry events. In this configuration, the abnormal weakening of the meridional component of the southeasterly wind from November-December to March-April associated with a positive anomaly of SST induces dry episodes over NNEB.

The composite of BLT on the NEA during the driest years shows a decrease of strong positive anomaly from NovemberDecember (0.32) to March-April (0.5). This decrease of the BLT is associated with a relative increase of the MLD. In this case, the $\mathrm{BL}$ that is previously thicker than normal in November-December decreases with the relaxation of the meridional PWS, which is associated with positive anomaly of the SST.

Figures 7(a) and 7(c) shows the evolution of the composite of SST and PWSx anomalies in the southwestern Atlantic warm pool (SAWP) $\left(30^{\circ}-15^{\circ} \mathrm{W}\right.$ and $15^{\circ}-5^{\circ} \mathrm{S}$ for SST and 
$30^{\circ}-15^{\circ} \mathrm{W}$ and $20^{\circ}-10^{\circ} \mathrm{S}$ for PWSx) from January-February to June-July during the wettest years (Figure $7(\mathrm{a})$ ) and the driest years (Figure 7(c)) at Recife. The composite is based on the 9 years of heavy rainfall (RAINA $>+0.5$, Figure 3 , Table 1) and the 9 years of very dry episodes (RAINA $<-0.5$, Figure 3, Table 1) at Recife. Positive (negative) anomalies of PWSx indicate weakening (strengthening) of the zonal component of the southeasterly wind. Although the SAWP does not represent the highest correlation of both SSTA and PWSx anomalies to ENEB rainfall, we considered the SAWP for averaging SSTA and PWSx anomalies to examine the time evolution of the zonal mode in the southern tropical Atlantic (see Figure 5, left-hand panels). The SAWP offshore of Brazil $\left(5^{\circ}-15^{\circ} \mathrm{S}\right.$ and $\left.30^{\circ}-20^{\circ} \mathrm{W}\right)$ is a region of weak seasonal to interannual variability of SST [29-33] where the standard deviation is $0.2-0.3^{\circ} \mathrm{C}$ for the monthly anomalies (see Figure 1(a)). This region also has the advantage of experiencing an inversion of the zonal wind anomaly from February-March to June-July (Figure 5, left-hand panels) near the Brazilian coast; this inversion should be important in the zonal transport of humidity to ENEB.

During years with strong positive rainfall anomalies at Recife, SSTA remains strongly positive in the SAWP from January-February to June-July, while PWSx presents positive anomalies (weak westward wind) during February-March and progressively intensifies to strong negative anomalies (strong westward wind) in June-July (Figure 7(a)).

Figure 7(b) shows the evolutions of the composite of MLD and BLT in the SAWP. The MLD that presents strong negative anomaly $(-0.45)$ in February-March and progressively increases to positive anomaly $(+0.22)$ in June-July while the BLT does not present a particular trend. The comparison of the evolution of the zonal component of the PWS with that of the MLD shows that wind intensification is associated with a deepening of the MLD in the SAWP. This pattern suggests that the abnormal intensification of the zonal component of the southeasterly wind from February-March to JuneJuly over the SAWP warm water, which is associated with a deepening of the MLD, transports more humidity to the ENEB coast. These observations support that the SAWP (region of weak variability of monthly SST anomalies) should be used as index of prediction for strong rainfall events in ENEB.

The opposite effect is observed during years of strong negative June-July rainfall anomalies in ENEB; the SST anomaly remains negative in the SAWP from January-February to June-July, while the zonal component of PWS, which presents a negative anomaly (strong westward wind) in FebruaryMarch, progressively decelerates to a positive anomaly (weak westward wind) in June-July (Figure 7(c)).

The analysis of the composite of the MLD during driest years shows a decrease of strong positive anomaly $(+0.5)$ in February-March to negative anomaly $(-0.1)$ in JuneJuly while the BLT does not present a particular trend (Figure 7(d)). The comparison of the evolution of the zonal component of the PWS with that of the MLD shows that wind relaxation is associated with a shallower MLD in the SAWP.
In this case, during years of negative SST anomalies in the SAWP, the abnormal relaxation of the zonal component of the southeasterly wind from February-March to June-July, associated with shallow MLD, over the relatively cold water of the SAWP is responsible for the dry episodes in ENEB.

\section{Summary}

Northeast Brazil experiences various rainfall regimes. Severe droughts occur in the interior countryside (semiarid region), while extreme precipitation events occur along the northern and eastern coasts. In both of these situations, the ocean plays an important role because the rainfall anomalies, whether negative or positive, occur through the exchange of mass, momentum, and heat with the surrounding and distant atmosphere. The influence of the tropical oceans on the occurrence of prolonged drought in the semiarid region of Northeast Brazil has been extensively studied. Scientific results suggest the remote influence of El Niño/La Niña events on the variability of SST anomalies in the tropical Atlantic, generating conditions of SST and trade winds that influence the southern migration of the ITCZ and rainfall.

In this study, we investigate the potential influence of the tropical Atlantic Ocean on the seasonal and interannual variability of rainfall at Fortaleza-NNEB and Recife-ENEB. This distinction is necessary because the rainfall regimes in these areas are variable throughout the year and suggest the occurrence of distinct (spatially and/or temporally) oceanic forcing on the rainfall variability.

We used the rainfall measurements for 1974-2008 at the Fortaleza and Recife meteorological stations, which are located in the NNEB and ENEB regions, respectively. Historical series of oceanic and atmospheric data, such as the SST and PWS, of the tropical Atlantic for different periods were analyzed and correlated with the rainfall measurements.

The results confirm the findings of previous studies that suggest that the seasonal and interannual variability of rainfall anomalies in NNEB is correlated with surface temperature anomalies in the tropical Atlantic on both sides of the equator, the AMM. In this configuration, a cooling of the northern portion of the tropical Atlantic, in conjunction with the above-average heating of the southern portion, induces the southward migration of the ITCZ; thus, anomalous rains occur in Fortaleza. A few months antecedent to the seasonal rainfall at Fortaleza, the positive southern pattern of the meridional SST dipole gradually develops, while the negative northern pattern continues to remain well organized in the northwestern equatorial Atlantic offshore of NEB. These analyses indicate a strong influence of the SST anomalies and meridional wind anomalies in the northwestern equatorial Atlantic, offshore of NEB, on the establishment of the AMM, and a predictive effect of this area on the NNEB rainfall. In contrast, the opposite oceanic conditions of the AMM, which are remotely strengthened by the occurrence of El Niño in the Pacific Ocean, hinder the southward migration of the ITCZ. This phenomenon plays a role in the long, dry periods that periodically affect NNEB and the semiarid region of Northeast Brazil. 
A different ocean-atmospheric configuration is verified in ENEB and influences the strong variability of rainfall. In this case, strong positive rainfall anomalies are positively correlated with SST in the southern tropical Atlantic. A negative correlation with SST is observed in the northern tropical Atlantic, primarily in the western area (from the coast to $40^{\circ} \mathrm{W}$ and $5^{\circ}-15^{\circ} \mathrm{N}$ ). Therefore, intense rainfall in this area generally occurs during negative phases of the AMM; however, the northwestward propagation of the SST anomaly from the southeastern tropical Atlantic $\left(15^{\circ}-0^{\circ} \mathrm{W}\right.$ and $10^{\circ}-$ $20^{\circ} \mathrm{S}$ ) to the SAWP offshore of Brazil is also a strong influence. The northwestward propagation has an estimated speed of $\sim 0.16 \mathrm{~m} / \mathrm{s}$, which is comparable to the mean velocity of the westward sSEC flow described in the literature. We believe that the sSEC acts as a primary pathway for cross-oceanic heat transport from the southeastern tropical Atlantic to the SAWP area offshore of Brazil. The equatorward direction of the area of intense positive correlation observed during June-July (0-month lag) along the Brazilian coast suggests a northward propagation of the ocean heat from the south tropical Atlantic to the Northern Hemisphere. We argue that this equatorward propagation of heat, which was previously transported from the southeastern tropical Atlantic to the Brazilian coast, joins the NBUC and the North Brazil Current (NBC) after bifurcation near the coast. Previous studies have shown that the equatorward current system along the Brazilian coast is responsible for the heat transport from the southern tropical Atlantic to the Northern Hemisphere $[40,43]$. In this configuration, the southeasterly wind intensification during the late boreal spring and the positive anomaly of sea surface temperature in the southern tropical Atlantic induce the westward transport of warm water via the southern branch of the SEC and the intense rainfall over ENEB during June-July. During the negative phase of the AMM, it appears that the zonal mode of the southern tropical Atlantic strongly influences ENEB rainfall. During negative (positive) AMM, positive (negative) anomalies of sea surface temperature in the SAWP from February-March to June-July favor (hinder) heat accumulation in the western part of the basin, which induces wet (dry) events in ENEB. The wind speed analysis corroborates the observation that the oceanic heat flux is transported from the SAWP to ENEB through the zonal surface wind convergence induced by the westward gradient [4]. During wet years, the zonal wind in the southwestern tropical Atlantic strengthens from February-March (positive anomalies) to June-July (negative anomalies); the opposite effect is observed for dry years. In definitive, it appears that a monitoring of SST and wind anomalies in the SAWP from February-March should be important for predicting June-July heavy rainfall or droughts events in ENEB.

The results presented here indicate that tropical Atlantic Ocean-atmosphere interactions uniquely influence NNEB and ENEB rainfall at seasonal and interannual time scales. The establishment of the AMM from November-December to March-April influences NNEB, while ENEB is mainly influenced by the zonal mode of the ocean-atmosphere interactions in the southern tropical Atlantic. The analysis of the mixed layer depth and the barrier layer thickness shows that the subsurface features of the NEA and SAWP differently influence the NNEB and ENEB heavy rainfall, respectively. Heavy rainfall in NNEB is mainly associated with barrier layer increase on the NEA while heavy rainfall in ENEB is associated with mixed layer increase on the SAWP. This observation should partially explain why strong rain anomalies in NNEB (ENEB) are associated with negative (positive) anomalies of SST in the NEA (SAWP). However, the oceanic contributions to Northeast Brazil rainfall remain unclear at the intraseasonal time scale, which includes an important forcing of high frequency extreme rain events observed in Northeast Brazil. However, the Agulhas rings, which derive from the current retroflection at the edge of South Africa, are the dominant mechanism by which warm and saline water flows from India to the Atlantic Ocean $[45,46]$. It would be interesting to investigate the influence of the core anomaly region related to the Agulhas eddy corridor on the interannual variability of the ocean-atmosphere anomalies observed in the southeastern tropical Atlantic, which has been shown to be an important early warning area for understanding and forecasting strong rainfall variability along the east coast of Northeast Brazil. It would also be important to do further investigations on the subsurface features of NEA and SAWP regions and their potential impact in NNEB and ENEB rainfall variability, respectively.

\section{Conflict of Interests}

The authors declare that there is no conflict of interests regarding the publication of this paper.

\section{Acknowledgments}

This work is a contribution of the INCT AmbTropic, the Brazilian National Institute of Science and Technology for Tropical Marine Environments, CNPq/FAPESB (Grants 565054/2010-4 and 8936/2011). G. A. Hounsou-gbo thanks Fundação de Amparo à Ciência e Tecnologia do Estado de Pernambuco (FACEPE) for Grant IBPG-0646-1.08/10 and the International Chair in Mathematical Physics and Applications (ICMPA-Unesco Chair), UAC. Bénin. J. Servain thanks CNPq for the Grant Pesquisador Visitante Especial (PVE) associated with Project Mudanças Climáticas no Atlântico Tropical (MUSCAT), Process No.: 400544/20130. FUNCEME (Project BTT FUNCEME/FUNCAP, Edital $10 / 2013$ ) is thanked for its support during the stay of J. Servain at Fortaleza, CE, Brazil.

\section{References}

[1] A. D. Moura and J. Shukla, "On the dynamics of droughts in northeast Brazil: observations, theory and numerical experiments with a general circulation model," Journal of the Atmospheric Sciences, vol. 38, no. 12, pp. 2653-2675, 1981.

[2] P. Nobre and J. Shukla, "Variations of sea surface temperature, wind stress, and rainfall over the tropical Atlantic and South America," Journal of Climate, vol. 9, no. 10, pp. 2464-2479, 1996.

[3] J. M. B. Alves, J. Servain, and J. N. B. Campos, "Relationship between ocean climatic variability and rain-fed agriculture in 
northeast Brazil," Climate Research, vol. 38, no. 3, pp. 225-236, 2009.

[4] Y. K. Kouadio, J. Servain, L. A. T. MacHado, and C. A. D. Lentini, "Heavy rainfall episodes in the eastern northeast brazil linked to large-scale ocean-atmosphere conditions in the tropical atlantic," Advances in Meteorology, vol. 2012, Article ID 369567, 16 pages, 2012.

[5] S. Hastenrath and L. Greischar, "Circulation mechanisms related to northeast Brazil rainfall anomalies," Journal of Geophysical Research, vol. 98, no. 3, pp. 5093-5102, 1993.

[6] V. B. Rao, M. C. De Lima, and S. H. Franchito, "Seasonal and interannual variations of rainfall over eastern northeast Brazil," Journal of Climate, vol. 6, no. 9, pp. 1754-1763, 1993.

[7] V. B. Rao, I. F. A. Cavalcanti, and K. Hada, "Annual variation of rainfall over Brazil and water vapor characteristics over South America," Journal of Geophysical Research D: Atmospheres, vol. 101, no. 21, pp. 26539-26551, 1996.

[8] S. Hastenrath, "Exploring the climate problems of Brazil's Nordeste: a review," Climatic Change, vol. 112, no. 2, pp. 243-251, 2012.

[9] D. E. Waliser and C. Gautier, "A satellite-derived climatology of the ITCZ," Journal of Climate, vol. 6, no. 11, pp. 2162-2174, 1993.

[10] R. G. Wagner, "Mechanisms controlling variability of the interhemispheric sea surface temperature gradient in the tropical Atlantic," Journal of Climate, vol. 9, no. 9, pp. 2010-2019, 1996.

[11] S. Hastenrath, "Circulation and teleconnection mechanisms of Northeast Brazil droughts," Progress in Oceanography, vol. 70, no. 2-4, pp. 407-415, 2006.

[12] V. E. Kousky and N. J. Ferreira, "Interdiurnal surface pressure variations in Brazil: their spatial distributions, origins and effects.," Monthly Weather Review, vol. 109, no. 9, pp. 1999-2008, 1981.

[13] A. Diedhiou, S. Janicot, A. Viltard, and P. de Felice, "Evidence of two regimes of easterly waves over West Africa and the tropical Atlantic," Geophysical Research Letters, vol. 25, no. 15, pp. 28052808, 1998.

[14] A. Diedhiou, L. A. T. Machado, and H. Laurent, "Mean kinematic characteristics of synoptic easterly disturbances over the Atlantic," Advances in Atmospheric Sciences, vol. 27, pp. 483499, 2010.

[15] L. A. T. Machado, R. L. Guedes, and M. A. S. Alves, "Structural characteristics of convective systems and forcing of convection in South America observed by satélites (Características Estruturais de Sistemas Convectivos e Forçantes da convecção na América do Sul observados por satélites)," Edição Comemorativa dos dez anos do Climanálise, pp. 110-122, 1997.

[16] H. Laurent, L. A. T. Machado, C. A. Morales, and L. Durieux, "Characteristics of the Amazonian mesoscale convective systems observed from satellite and radar during the WETAMC/LBA experiment," Journal of Geophysical Research D: Atmospheres, vol. 107, no. 20, pp. LBA 21-1-LBA 21-17, 2002.

[17] C. Wang, D. B. Enfield, S.-K. Lee, and C. W. Landsea, "Influences of the Atlantic warm pool on western hemisphere summer rainfall and Atlantic hurricanes," Journal of Climate, vol. 19, no. 12, pp. 3011-3028, 2006.

[18] D. B. Lucena, J. Servain, and M. F. G. Filho, "Rainfall response in Northeast Brazil from ocean climate variability during the second half of the 20th century," Journal of Climate, vol. 24, no. 23, pp. 6174-6184, 2011.

[19] A. W. Robertson, C. R. Mechoso, and Y.-J. Kim, "The influence of Atlantic sea surface temperature anomalies on the North
Atlantic oscillation," Journal of Climate, vol. 13, no. 1, pp. 122$138,2000$.

[20] R. Zhang and G. K. Vallis, "Impact of great salinity anomalies on the low-frequency variability of the North Atlantic climate," Journal of Climate, vol. 19, no. 3, pp. 470-482, 2006.

[21] J. Servain, J. Picaut, and A. J. Busalacchi, "Chapter 16 interannual and seasonal variability of the tropical atlantic ocean depicted by sixteen years of sea-surface temperature and wind stress," Elsevier Oceanography Series, vol. 40, pp. 211-237, 1985.

[22] J. Servain, M. Séva, S. Lukas, and G. Rougier, "Climatic atlas of the tropical Atlantic wind stress and sea surface temperature: 1980-1984," Ocean-Air Interactions, vol. 1, pp. 109-182, 1987.

[23] J. Servain and S. Lukas, Climatic Atlas of the Tropical Atlantic Wind Stress and Sea Surface Temperature 1985-1989, vol. 70, IFREMER, Plouzané, France, 1990.

[24] S. R. Smith, J. Servain, D. M. Legler, J. N. Stricherz, M. A. Bourassa, and J. J. O'Brien, "In situ-based pseudo-wind stress products for the tropical oceans," Bulletin of the American Meteorological Society, vol. 85, no. 7, pp. 979-994, 2004.

[25] L. Yu and R. A. Weller, "Objectively analyzed air-sea heat fluxes for the global ice-free oceans (1981-2005)," Bulletin of the American Meteorological Society, vol. 88, no. 4, pp. 527-539, 2007.

[26] L. Yu, X. Jin, and R. A. Weller, "Multidecade Global Flux Datasets from the Objectively Analyzed Air-sea Fluxes (OAFlux ) Project: Latent and sensible heat fluxes, ocean evaporation, and related surface meteorological variables," Tech. Rep. OA2008-1, Woods Hole Oceanographic Institution, 2008.

[27] L. Yu and X. Jin, "Buoy perspective of a high-resolution global ocean vector wind analysis constructed from passive radiometers and active scatterometers (1987-present)," Journal of Geophysical Research C, vol. 117, no. 11, Article ID C11013, 2012.

[28] J. Picaut, "Propagation of the seasonal upwelling in the eastern equatorial Atlantic," Journal of Physical Oceanography, vol. 13, no. 1, pp. 18-37, 1983.

[29] M. Silva, M. Araujo, J. Servain, and P. Penven, "Circulation and heat budget in a regional climatological simulation of the southwestern tropical Atlantic," Tropical Oceanography, vol. 39, pp. 41-57, 2009.

[30] M. Silva, M. Araujo, J. Servain, P. Penven, and C. A. D. Lentini, "High-resolution regional ocean dynamics simulation in the southwestern tropical Atlantic," Ocean Modelling, vol. 30, no. 4, pp. 256-269, 2009.

[31] C. M. Limongi, M. Araujo, I. C. Freitas, and M. Rollnic, "Massas d'água da região oeste do Atlântico tropical-ZEE-NE," in Meteorologia e Sensoriamento Remoto, Oceanografia Física, Oceanografia Química e Oceanografia Biológica-Program REVIZEE-SCORE Nordeste, F. H. V. Hazin, Ed., vol. 1, pp. 5668, Martins \& Cordeiro, Fortaleza, Brazil, 1st edition, 2009.

[32] C. M. Limongi, M. Araujo, M. Rollnic, and I. C. Freitas, "Estrutura termohalina da região oeste do Atlântico tropical-ZEE-NE," in Meteorologia e Sensoriamento Remoto, Oceanografia Física, Oceanografia Química e Oceanografia Biológica-Program REVIZEE-SCORE Nordeste, F. H. V. Hazin, Ed., vol. 1, pp. 40-54, Martins \& Cordeiro, Fortaleza, CE, Brazil, 2009.

[33] M. Araujo, C. M. Limongi, J. Servain et al., "Salinity-induced mixed and barrier layers in the Southwestern tropical Atlantic Ocean off the Northeast of Brazil," Ocean Science, vol. 7, no. 1, pp. 63-73, 2011.

[34] J. Mignot, C. de Boyer Montégut, A. Lazar, and S. Cravatte, "Control of salinity on the mixed layer depth in the world ocean: 
2. Tropical areas," Journal of Geophysical Research C: Oceans, vol. 112, no. 10, Article ID C10010, 2007.

[35] M. Araujo, C. Limongi, J. Servain et al., "Salinity-induced mixed and barrier layers in the Southwestern tropical Atlantic Ocean off the Northeast of Brazil," Ocean Science, vol. 7, no. 1, pp. 63-73, 2011.

[36] J. Sprintall and M. Tomczak, "Evidence of the barrier layer in the surface layer of the tropics," Journal of Geophysical Research, vol. 97, pp. 7305-7316, 1992.

[37] J. Vialard and P. Delecluse, "An OGCM study for the TOGA decade. Part I: role of salinity in the physics of the western Pacific fresh pool," Journal of Physical Oceanography, vol. 28, no. 6, pp. 1071-1088, 1998.

[38] C. de Boyer Montégut, G. Madec, A. S. Fischer, A. Lazar, and D. Iudicone, "Mixed layer depth over the global ocean: an examination of profile data and a profile-based climatology," Journal of Geophysical Research C, vol. 109, no. 12, 2004.

[39] J. Servain, "Simple climatic indices for the tropical Atlantic Ocean and some applications," Journal of Geophysical Research, vol. 96, no. 8, pp. 15137-15146, 1991.

[40] L. Stramma, "Geostrophic transport of the South Equatorial Current in the Atlantic," Journal of Marine Research, vol. 49, pp. 281-294, 1991.

[41] P. L. Richardson and T. K. McKee, "Average seasonal variation of the Atlantic equatorial currents from historical ship drifts," Journal of Physical Oceanography, vol. 14, pp. 1226-1238, 1984.

[42] R. R. Rodrigues, L. M. Rothstein, and M. Wimbush, "Seasonal variability of the South Equatorial Current bifurcation in the Atlantic Ocean: a numerical study," Journal of Physical Oceanography, vol. 37, no. 1, pp. 16-30, 2007.

[43] F. A. Schott, J. Fischer, and L. Stramma, "Transports and pathways of the upper-layer circulation in the western tropical Atlantic," Journal of Physical Oceanography, vol. 28, no. 10, pp. 1904-1928, 1998.

[44] L. Stramma, J. Fischer, P. Brandt, and F. Schott, "Circulation, variability and near-equatorial meridional flow in the central tropical Atlantic," Elsevier Oceanography Series, vol. 68, pp. 122, 2003.

[45] M. Rouault, P. Penven, and B. Pohl, "Warming in the agulhas current system since the 1980's," Geophysical Research Letters, vol. 36, no. 12, pp. 1-5, 2009.

[46] L. M. Beal, W. P. M. de Ruijter, A. Biastoch et al., "On the role of the Agulhas system in ocean circulation and climate," Nature, vol. 472, no. 7344, pp. 429-436, 2011. 

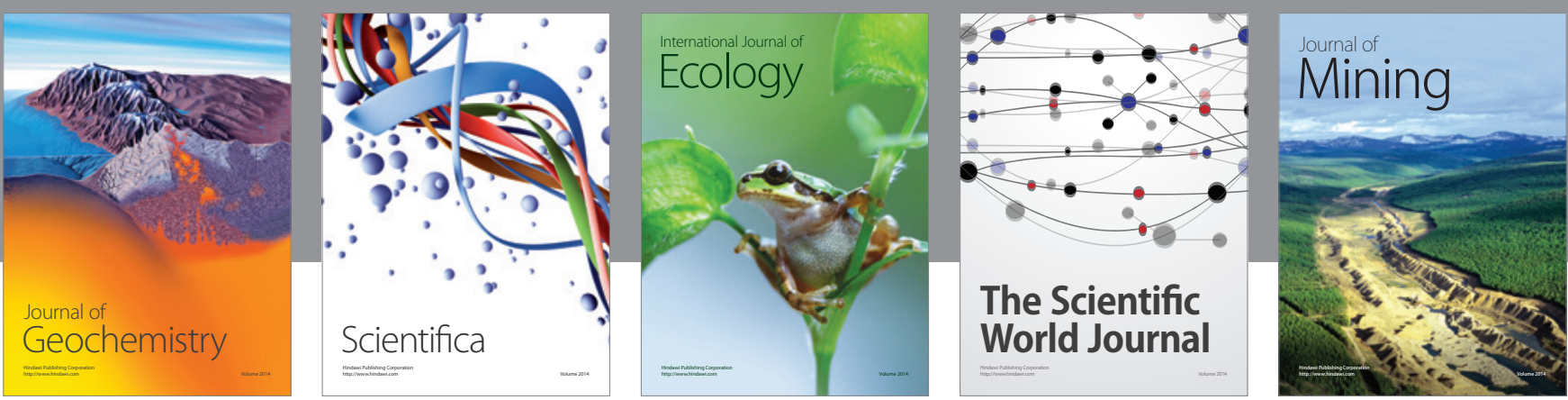

The Scientific World Journal
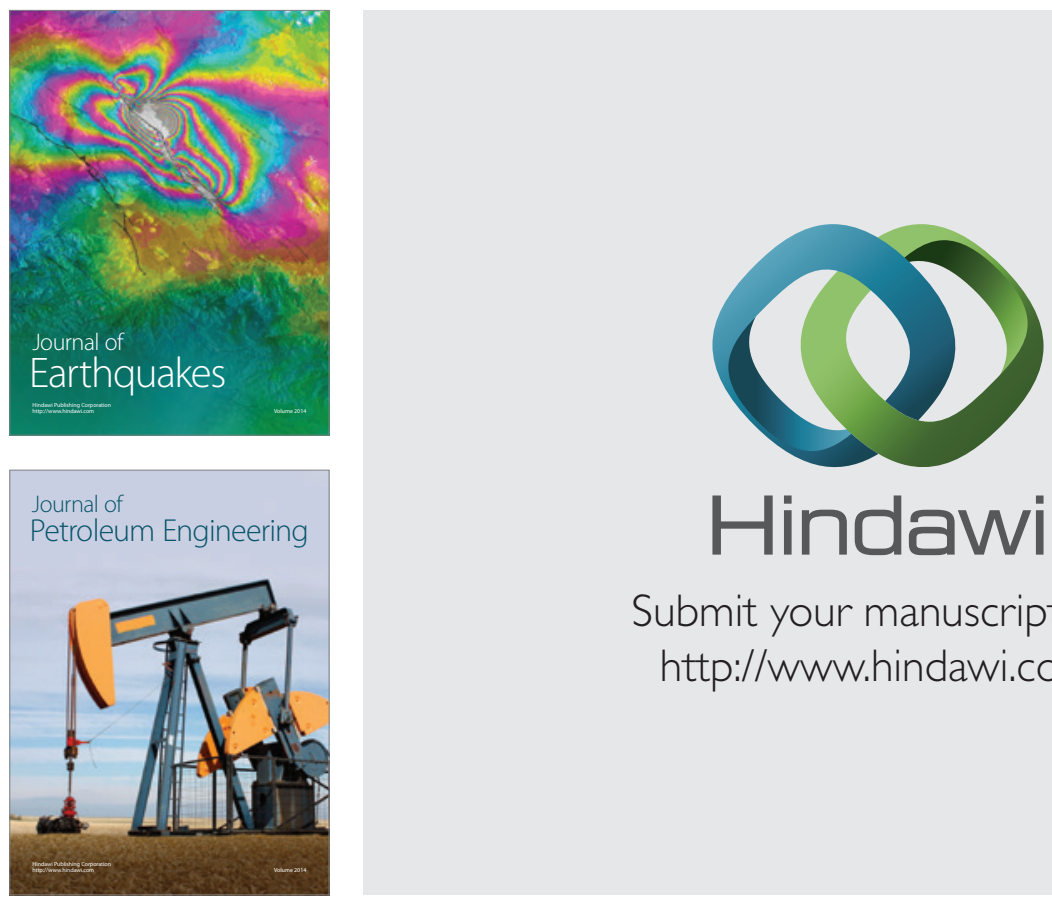

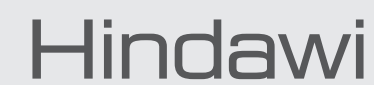

Submit your manuscripts at

http://www.hindawi.com
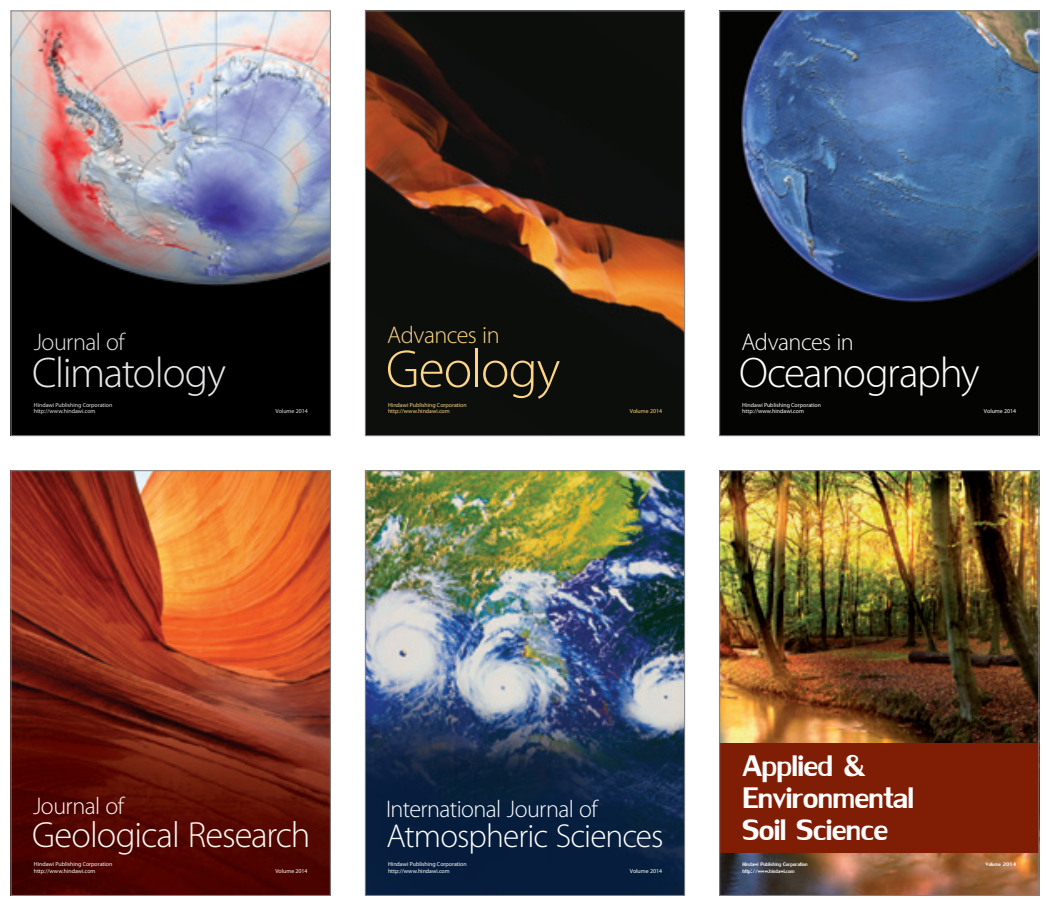
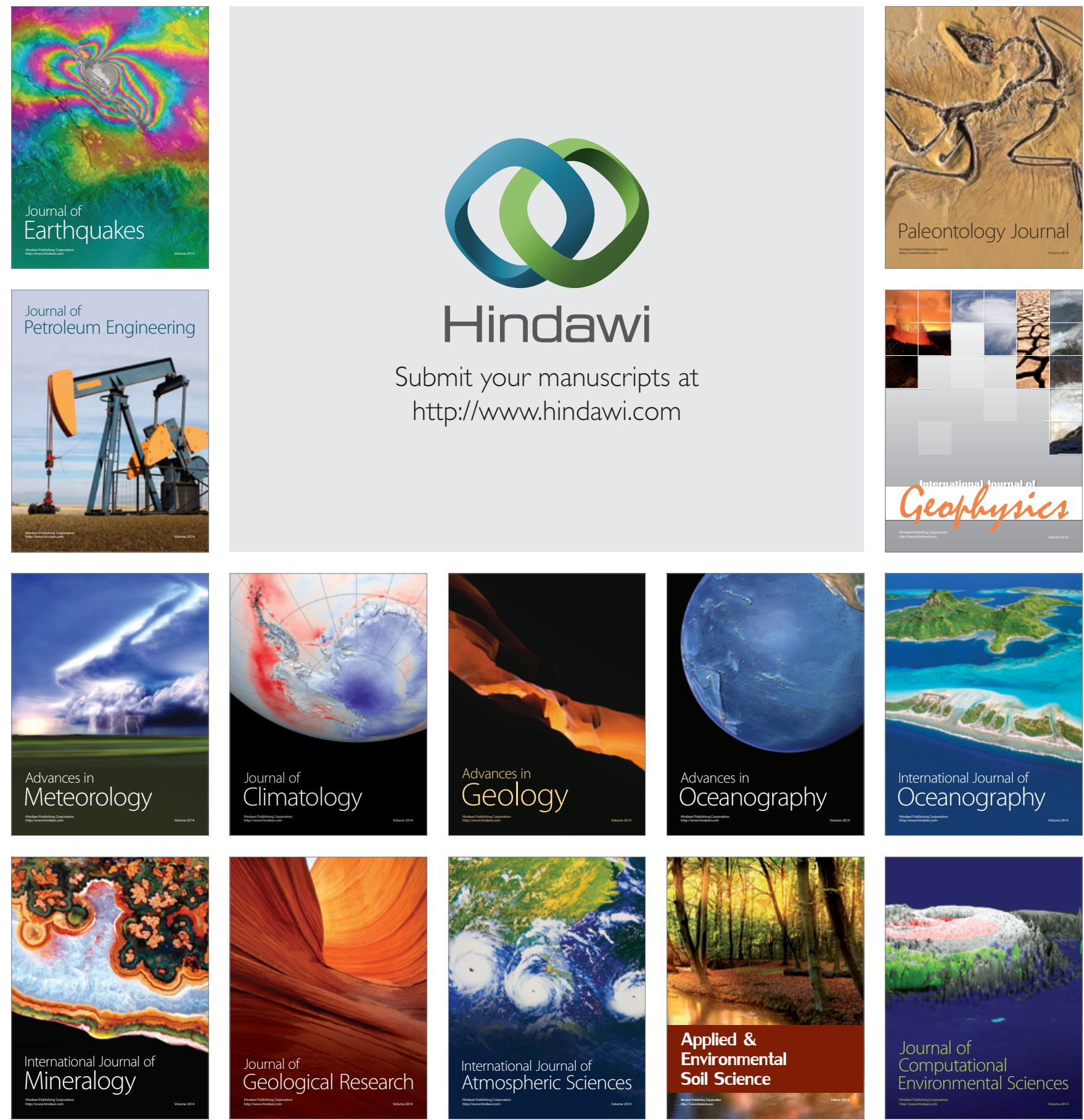